\title{
Linkage relationships between the loci Sec 1 and Sec 3 in rye (Secale cereale L.)
}

J. M. Carrillo,

J. F. Vazquez and

J. Orellana
Departamento de Genética, Escuela Técnica Superior de Ingenieros Agrónomos, Universidad Politécnica, 28040 Madrid, Spain.

Rye secalins were analyzed in the progeny of three test-crosses by sodium dodecyl sulphate polyacrylamide gel electrophoresis (SDS-PAGE) using unreduced and reduced extracts of total seed proteins. Segregation for two $\omega$ secalin bands and two $40 \mathrm{~K} \gamma$-secalin bands was studied in the three crosses. Both kinds of proteins showed a very tight linkage (0.25 $\pm \mathbf{0} \cdot 25$ per cent recombination), finding one recombinant in 394 seeds. Segregation for two high molecular weight (HMW) secalin bands was analyzed in one test-cross. The data indicated linkage $(36 \cdot 03 \pm 4 \cdot 12$ per cent recombination) between the structural genes for $\omega$ and $40 \mathrm{~K} \gamma$ secalins (Sec 1) and for HMW secalins (Sec 3).

\section{INTRODUCTION}

In rye, four major groups of storage proteins (secalins) have been purified and characterized (Shewry et al., 1982; Field et al., 1982; Shewry et al., 1983; Kasarda et al., 1983). These four groups are called high molecular weight secalins, $75 \mathrm{~K}$ $\gamma$-secalins, $\omega$-secalins, and $40 \mathrm{~K} \gamma$-secalins. The structural genes for the group of high molecular weight (HMW) secalins were located on the long arm of chromosome 1R (Lawrence and Shepherd, 1981; Singh and Shepherd, 1984; Shewry et al., 1984 ), and for the other two groups, the $\omega$-secalins and the $40 \mathrm{~K} \gamma$-secalins, on the short arm of the same chromosome (Shepherd, 1968; Bernard et al., 1977; Lawrence and Shepherd, 1981). The locus on the long arm has been designated Sec 3, and the locus on the short arm Sec 1 (Shewry et al., 1984). The structural genes for the fourth group, the $75 \mathrm{~K} \gamma$-secalins, were located on chromosome $2 \mathrm{R}$ in $S$. cereale (Lawrence and Shepherd, 1981) and its locus has been called Sec 2 (Shewry et al., 1984). In the ancient species $S$. montanum they were located on 6R (Shewry et al., 1985).

The linkage relationships of the structural genes for some secalins have been determined. Shewry et al. (1984), Lawrence and Appels (1986) estimated the linkage between the loci on chromosome $1 \mathrm{R}$ responsible of HMW and $\omega$-secalins, studying the segregation of one band of each kind of proteins. The locus Sec 3 which controls the
HMW secalins was mapped close to the centromere (Singh and Shepherd, 1984).

This paper reports the segregation of some secalin bands among progeny of three test-crosses in rye. Segregation occurred at the Sec 1 locus for $\omega$ and $40 \mathrm{~K} \gamma$ secalins and at $\mathrm{Sec} 3$ for HMW secalins. Our results indicate that $\operatorname{Sec} 1$ is a complex locus with families of genes tightly linked and also show that Sec 3 and Sec 1 loci are loosely linked.

\section{MATERIAL AND METHODS}

\section{Crossing scheme}

Some plants from a population of Secale cereale were pollinated with pollen from a $3 \mathrm{R}$ telocentric substitution line cv. "Petkus Spring". Three $F_{1}$ grains, coming from the same spike were sown and the $F_{1}$ plants were test-crossed to study segregation in secalins. One of them was pollinated by the inbred line A of $S$. cereale (cross 1), and the other two $F_{1}$ were crossed as females by the inbred line $\mathrm{R}$ of $S$. cereale (crosses 2 and 3 ). Both inbred lines have been maintained by selfing about thirty years.

\section{Extraction and analysis of seed proteins}

The grains obtained from the three crosses were divided in two halves. From one half total proteins were extracted into a buffered solvent containing 
4 per cent $(w / v)$ sodium dodecyl sulphate (SDS) and 5 per cent $(\mathrm{v} / \mathrm{v})$ 2-mercaptoethanol (2-ME), and from the other half the extraction was in the same solvent without 2-ME. The extracted proteins were fractionated by SDS-PAGE using 12 per cent gels in the discontinuous system of Laemmli (1970) as modified by Payne et al. (1980). Half grain of the three $F_{1}$ grains and some grains of the inbred lines were kept and analysed in the same way as the half grains of the crosses.

Apparent molecular weights of rye proteins were determined from the movilities of the following proteins included in the MW-SDS-200 kit (Sigma): myosin $(205,000), \quad \beta$-galactosidase $(116,000)$, phosphorylase B $(97,400)$, bovine albumin $(66,000)$, egg albumin $(45,000)$, and carbonic anhydrase $(29,000)$.

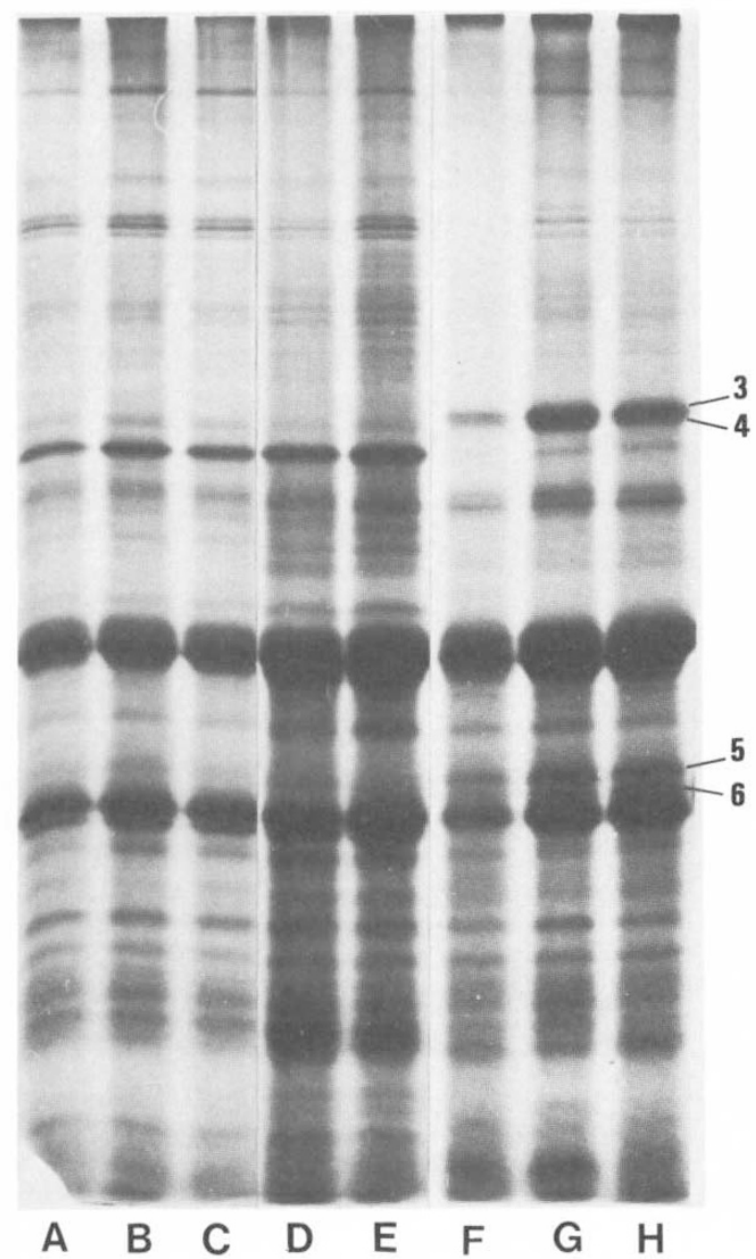

Figure 1 Fractionation by SDS-PAGE of unreduced total seed proteins. A-C, inbred line R; D-E; inbred line A; F-H, the three $F_{1}$ grains used in test-crosses.

\section{Statistical analysis}

Gene linkage was tested for by $\chi^{2}$ tests, and recombination fractions and their standard errors were estimated by the method of maximum likelihood.

\section{RESULTS AND DISCUSSION}

The three $F_{1}$ grains showed the same patterns in each extraction procedure of total endosperm proteins, without 2-ME (fig. 1, slots F-H) and reducing the extracts (fig. 2, slots I-J). Slots A-E (fig. 1) and slots B-H (fig. 2) show separations of secalins from several grains of the inbred lines $\mathrm{R}$ and $\mathrm{A}$ used for the test-crosses. The pattern of all grains analysed within each line showed the homogeneity expected of inbred lines with reduced and unreduced proteins.

The segregation of seed protein differences was examined in the progeny of the three test-crosses. Secalin patterns without reduction are shown in fig. 3 , where unreduced proteins of six grains from

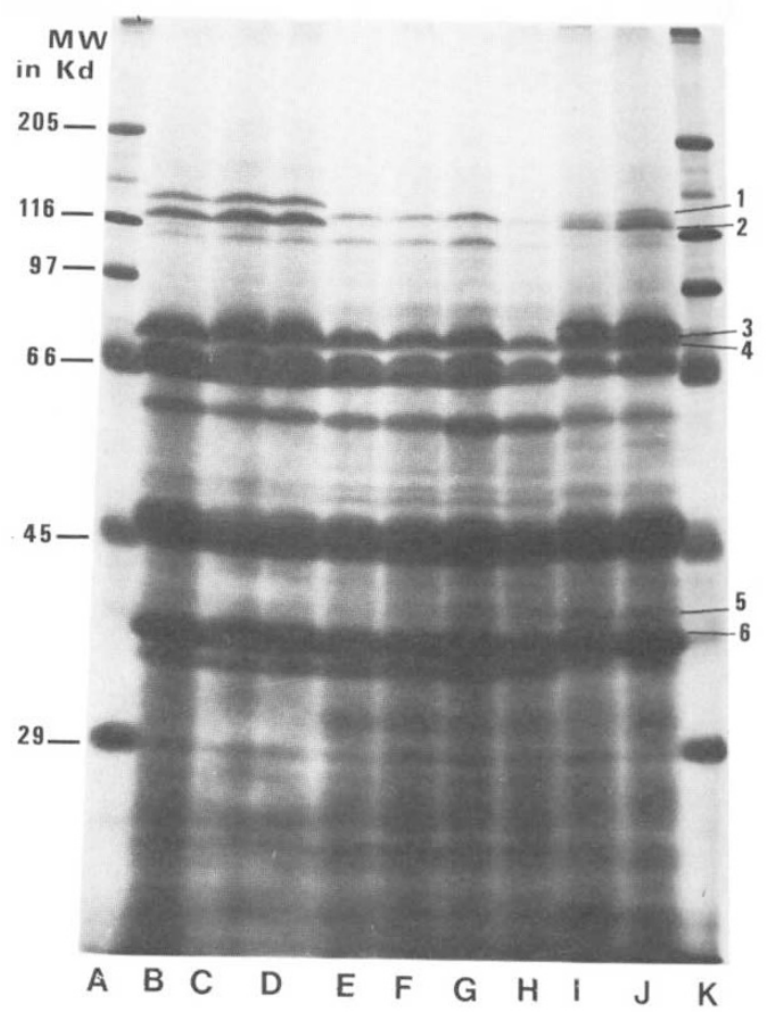

Figure 2 Fractionation by SDS-PAGE of reduced total seed proteins. A and $\mathrm{K}$, molecular weight markers; B-D, inbred line $\mathrm{R} ; \mathrm{E}-\mathrm{H}$, inbred line $\mathrm{A} ; \mathrm{I}$ and $\mathrm{J}$, the $\mathrm{F}_{1}$ grains used in the test-crosses 1 and 2. 


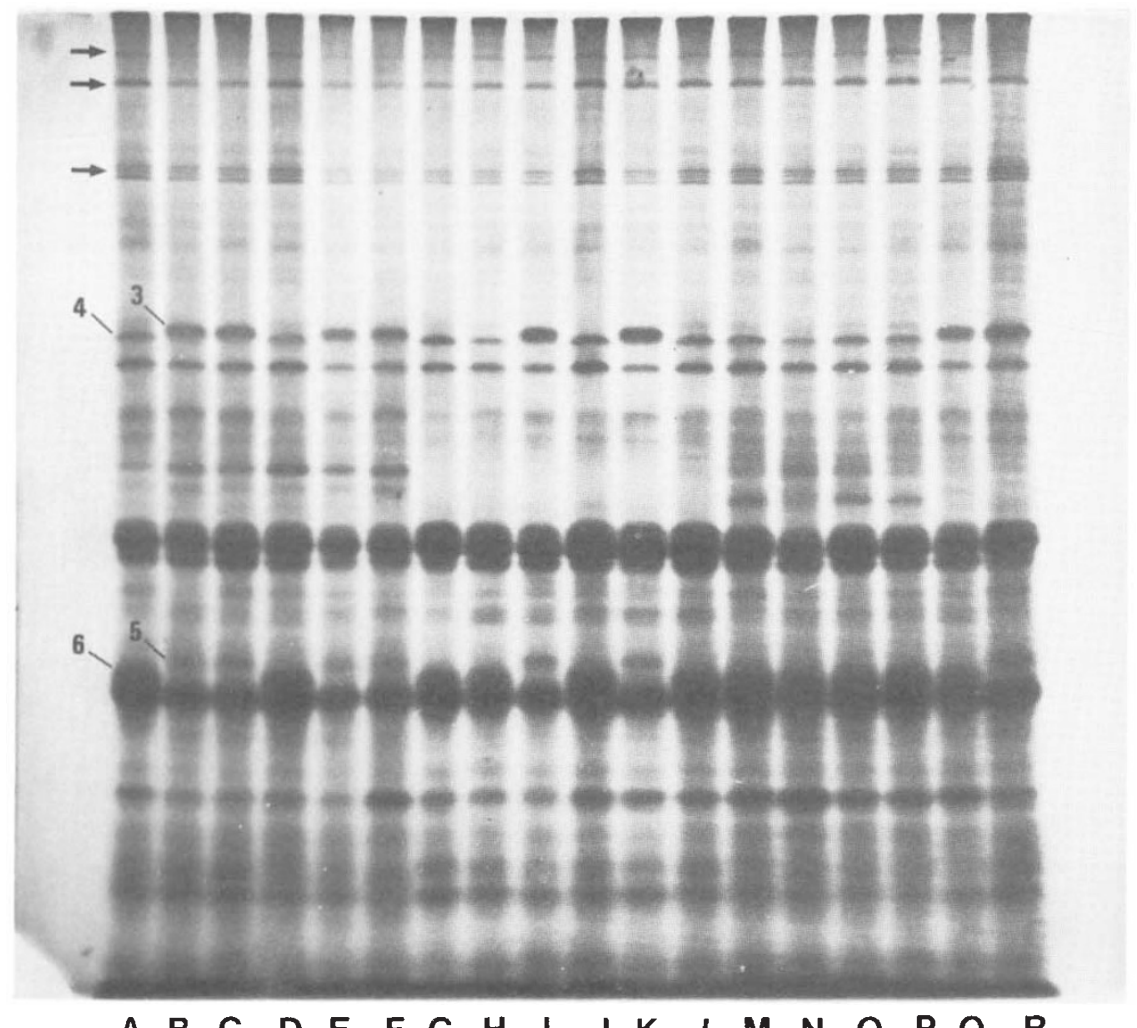

A B C D E F G H I J $K$ K L M $N$ N O $P$ Q $Q R$

Figure 3 SDS-PAGE of unreduced total seed proteins. A-F, single seeds from progeny of test-cross 1; G-L, single seeds from progeny of test-cross $2 ; \mathrm{M}-\mathrm{R}$, single seeds from progeny of test-cross 3 .

each cross were separated by SDS-PAGE. In the upper (cathodal) part of the gel some uniform bands appeared (arrowed in fig. 3), and these bands were absent after reduction with ME (fig. 4). In wheat the only bands found, without reduction, in the high molecular weight region are the triplet protein bands (Singh and Shepherd, 1985). In rye more protein bands than in wheat were found. The reason could be that the aggregated proteins resulting from disulphide linkage could have smaller size in rye than in wheat and therefore they could penetrate easier the pores of the gel.

The other faster moving protein bands in unreduced extracts were thought to be monomeric secalins and soluble proteins (albumins and globulins). In the progeny of the three test-crosses band 3 was inherited as an alternative to band 4 (fig. 3). Band 5 was also an alternative to band 6 (fig. 3). The segregation in both situations and in the three crosses was statistically in agreement with a $1: 1$ ratio, consistent with the band 3 being allelic to band 4 , and band 5 to band 6 .

In fig. 4 , showing reduced total proteins extracted from the other halves of the same grains, bands
$3,4,5$, and 6 are distinguishable in the three crosses. Their segregation in reduced extracts was exactly the same as in unreduced extracts of the other half grains.

Bands 3, 4, and 5, 6 were assigned to the $\omega$-secalin and $40 \mathrm{~K} \gamma$-secalin classes of proteins respectively. Bands 3 and 4 were more clearly resolved without reduction. Their mobilities (fig. 4) indicated that bands 3 and 4 were located in the mobility zone of $75 \mathrm{~K} \gamma$-secalin proteins controlled by the Sec 2 locus on chromosome $2 \mathrm{R}$ (Lawrence and Shepherd, 1981; Shewry et al., 1984). The molecular weight of these $\omega$-secalins was considerably higher than the weight determined, about $52 \mathrm{Kd}$, for $\omega$-secalins (Shewry et al., 1983). This was to be expected. Shewry et al. (1984) mapped an $\omega$-secalin band very close to $75 \mathrm{~K} \gamma$ secalin region and Lawrence and Appels (1986) mapped another $\omega$-secalin band located among $75 \mathrm{~K} \gamma$-secalins, in a very similar location to that of bands 3 and 4 . In barley and wheat the homologous proteins to $\omega$-secalins have a wide range in their molecular weights (Faulks et al., 1981; Kasarda et al., 1983). 


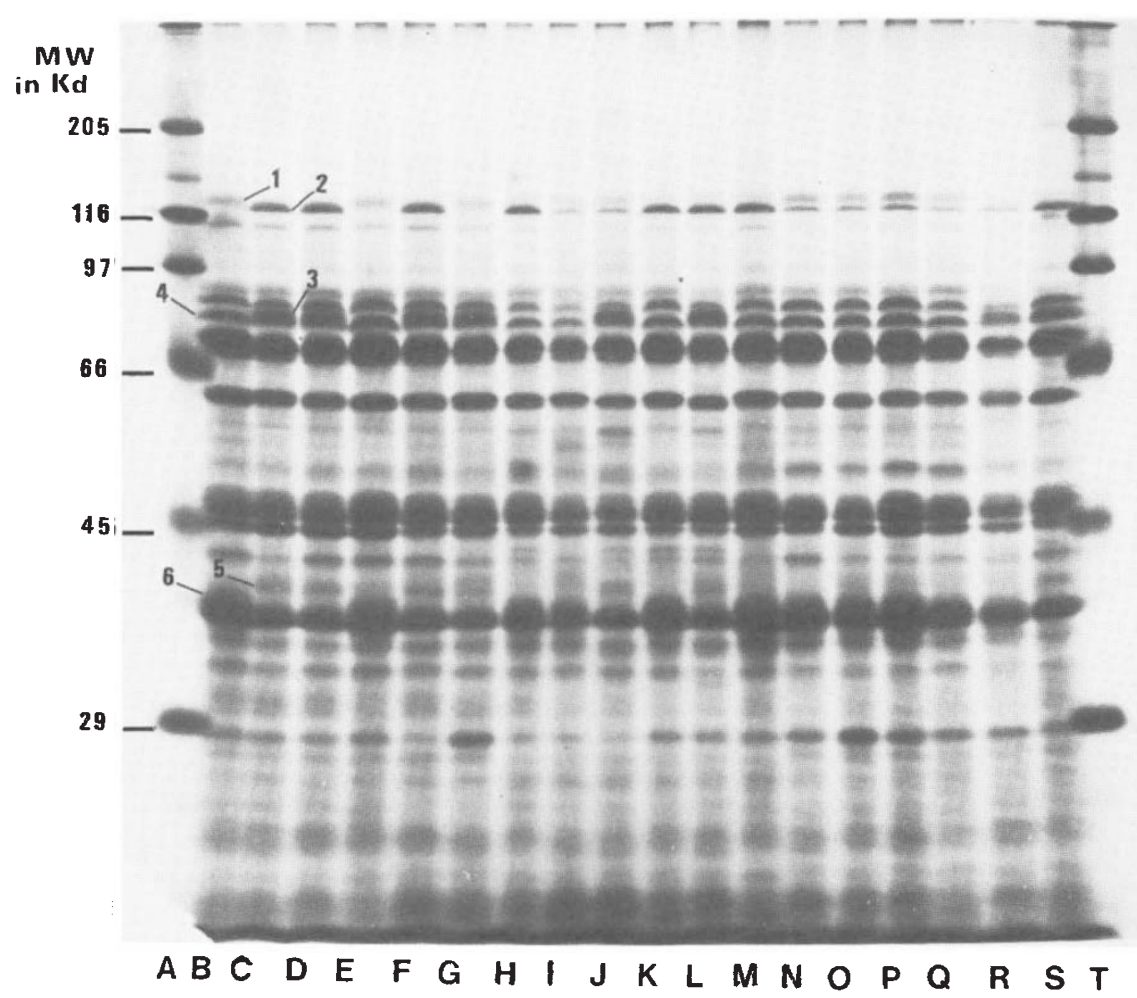

Figure 4 SDS-PAGE of reduced total seed proteins. A and T, molecular weight markers; B-G, single seeds from progeny of test-cross $1 ; \mathrm{H}-\mathrm{M}$, single seeds from progeny of test-cross $2 ; \mathrm{N}-\mathrm{S}$, single seeds from progeny of test-cross 3 .

Bands 5 and 6 were distinguishable in reduced and unreduced total protein extracts and their mobilities suggested that they belonged to the group of $40 \mathrm{~K} \gamma$-secalins, being controlled, as the $\omega$-secalins, by the Sec 1 locus located on the short arm of 1R (Shewry et al., 1984). Both kinds of proteins, $40 \mathrm{~K} \gamma$-secalins and $\omega$-secalins, showed complete linkage in crosses 1 and 2, and one recombinant with bands 3 and 6 was found in cross 3 (fig. 3, slot $Q$ and fig. 4, slot R). The numbers of various phenotypic classes and the linkage values are given in table 1 . The recombination percentage in cross 3 was $0 \cdot 91 \pm 0 \cdot 90$. Combining the results of the three crosses the recombination percentage was $0 \cdot 25 \pm 0 \cdot 25$. Shewry et al. (1984) suggested that the genes responsible for the $40 \mathrm{~K} \gamma$-secalins were linked to those for the $\omega$-secalins, but a precise linkage relationship of the genes for the $\gamma$-secalins had not been established. Sec 1 seems to be a complex locus controlling $\omega$ and $40 \mathrm{~K} \gamma$ secalins with at least two families of genes very tightly linked. It should be necessary to study more segregates to confirm that the situation in Sec 1 is similar to the homologous Gli-1 loci in wheat where the

Table 1 Phenotypic classes, linkage $\chi^{2}$ and recombination percentages for the $\omega$ and $40 \mathrm{~K} \gamma$ secalin bands segregating in Sec 1 locus, amongst progenies from three test-crosses

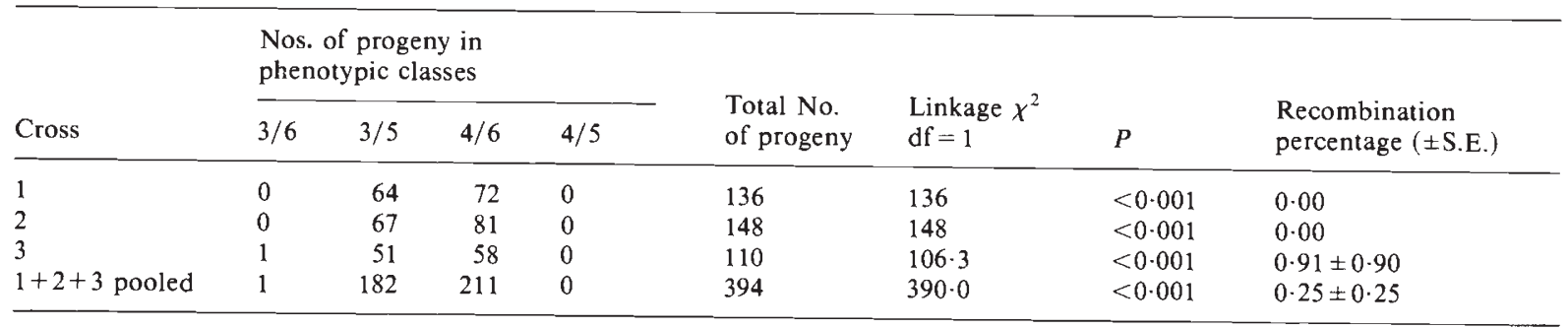


Table 2 Phenotypic classes, linkage $\chi^{2}$ and recombination percentages for the bands segregating in Sec 1 and Sec 3 , amongst progeny from one test-cross

\begin{tabular}{|c|c|c|c|c|c|c|c|c|}
\hline Secalin bands & $\begin{array}{l}\text { Nos. } \\
\text { phen }\end{array}$ & $\begin{array}{l}\text { proge } \\
\text { pic cl }\end{array}$ & $\begin{array}{l}\text { in } \\
\text { ses }\end{array}$ & & $\begin{array}{l}\text { Total No. } \\
\text { of progeny }\end{array}$ & $\begin{array}{l}\text { Linkage } \chi^{2} \\
\mathrm{df}=1\end{array}$ & $P$ & $\begin{array}{l}\text { Recombination } \\
\text { percentage }( \pm \mathrm{SE})\end{array}$ \\
\hline \multirow[t]{2}{*}{$H M W \cdot \omega$} & $1 / 3$ & $1 / 4$ & $2 / 3$ & $2 / 4$ & & & & \\
\hline & 42 & 27 & 22 & 45 & 136 & $10 \cdot 62$ & $<0.005$ & $36 \cdot 03 \pm 4 \cdot 12$ \\
\hline HMW-40K $\gamma$ & $1 / 6$ & $1 / 5$ & $2 / 6$ & $2 / 5$ & & & & \\
\hline
\end{tabular}

genes controlling $\omega$ and $\gamma$ gliadins bands have been shown to segregate as a unit with nil or very rare recombination (Sozinov and Poperelya, 1980; Metakovsky et al., 1984).

The mobility of the slower bands in fig. 4 indicated that they were HMW secalins. They were absent in unreduced extracts (fig. 3) and were separated only in the presence of a reducing agent, which breaks the disulphide bonds separating the aggregates formed by the HMW secalins (Shewry et al., 1983). Their structural genes were assigned to the Sec 3 locus located on the long arm of $1 \mathrm{R}$ (Lawrence and Shepherd, 1981; Singh and Shepherd, 1984; Shewry et al., 1984). It was possible to study segregation of bands 1 and 2 in test-cross 1 (fig. 4, slots B-G), but in the other two test-crosses the protein bands of inbred line $\mathrm{R}$ did not allow us to analyze clearly the segregation. Bands 1 and 2 were alternative and their segregation was in agreement with a $1: 1$ ratio. These HMW secalin bands were linked to $3,4 \omega$-secalin bands and to $5,640 \mathrm{~K} \gamma$-secalin bands (table 2 ). The recombination percentage between $\operatorname{Sec} 3$ and Sec 1 was $36 \cdot 03 \pm 4 \cdot 12$, in complete agreement with the estimate of $36 \pm 4 \cdot 6$ obtained by Lawrence and Appels (1986), and comparable to the recombination value of $40 \cdot 8 \pm 3 \cdot 76$ reported by the other mapping study of secalins in $1 \mathrm{R}$ of Secale cereale (Shewry et al., 1984).

Acknowledgements We thank J. Rodríguez and C. Lladó for their technical assistance. This work was supported by a grant No. AGR88-0051 from Comisión Interministerial de Ciencia y Tecnología (CICYT) of Spain.

\section{REFERENCES}

BERNARD, M., AUTRAN, J.-C. AND JOUDRIER, P. 1977. Possibilités d'identification de certains chromosomes de seigle à laide de marqueurs biochimiques. Ann. Amelior. Plantes, 27, 355-362.
FAULKS, A. S., SHEWRY, P. R. AND MIFLIN, B. S. 1981. The polymorphism and structural homology of storage polypeptides (hordein) coded by the Hor 2 locus in barley (Hordeum vulgare L.). Biochem. Genet., 19, 841-858.

FIELD, J. M., SHEWRY, P. R., MARCH, J. AND MIFLIN, B. J. 1982. The purification and characterization of homologous high molecular weight storage proteins from grain of wheat, rye and barley. Theor. Appl. Genet, 62, 329-336.

KASARDA, D. D., AUTRAN, J.-C., LEW, E. J.-L., NIMMO, C. C. AND SHEWRY, P. R. 1983. N-terminal amino acid sequences of $\omega$-glia dins and $\omega$-secalins: implications for the evolution of prolamin genes. Biochem. Biophys. Acta, 747, 138-150.

LAEMMLI, V. K. 1970. Cleavage of structural proteins during the assembly of the head of bacteriophage T4 Nature, 227, 681-684.

LAWRENCE, G. J. AND SHEPHERD, R. W. 1981. Chromosomal location of genes controlling seed proteins in species related to wheat. Theor. Appl. Genet., 59, 25-31.

LAWRENCE, G. J. AND APPELS, R. 1986. Mapping the nucleolus organizer region, seed protein loci and isozyme loci on chromosome 1R in rye. Theor. Appl. Genet., 71, $742-749$.

METAKOVSKY, E. V., NOVOSELSKAYA, A. YU., KOPUS, M. M., SOBKO, T. A. AND SOZINOV, A. A. 1984. Blocks of gliadin components in winter wheat detected by one-dimensional polyacrylamide gel electrophoresis. Theor. Appl. Genet. 67, 559-568.

PAYNE, P. I., LAW, C. N. AND MUDD, E. E. 1980. Control by homoeologous group 1 chromosomes of the highmolecular-weight subunits of glutenin, a major protein of wheat endosperm. Theor. Appl. Genet., 58, 113-120.

SHEPHERD, K. W. 1968. Chromosomal control of endosperm proteins in wheat and rye. In Finlay, K. W. and Shepherd, K. W. (eds) Proc. 3rd Int. Wheat Genet. Symp., Plenum Press, New York, pp. 86-96.

SHEWRY, P. R., BRADBERRY, D., FRANKLIN, J. AND WHITE, P. R. 1984. The chromosomal locations and linkage relationships of the structural genes for the prolamin storage proteins (secalins) of rye. Theor. Appl. Genet., 69, 63-69.

SHEWRY, P. R., FIELD, J. M., LEW, E. J-L. AND KASARDA, D. D. 1982. The purification and characterization of two groups of storage protein (secalins) from rye (Secale cereale L.). J. Exp. Bot., 133, 261-268.

SHEWRY, P. R., PARMAR, S. AND MIFLIN, B.S. 1983. Extraction, separation and polymorphism of the prolamine storage proteins (secalins) of rye. Cereal Chem., 60, 1-6.

SHEWRY, P. R., PARMAR, S. AND MILLER, T. E. 1985. Chromosomal location of the structural genes for the $M_{r} 75,000$ $\gamma$-secalins in Secale montanum Guss: evidence for a translocation involving chromosomes $2 \mathrm{R}$ and $6 \mathrm{R}$ in cultivated rye (Secale cereale L.). Heredity, 54, 381-383. 
SINGH, N. K. AND SHEPHERD, K. W. 1984. Mapping of the genes controlling the high-molecular-weight glutelin subunits of rye on the long arm of chromosome 1R Genet. Res. Camb., 44, 117-123.

SINGH, N. K. AND SHEPHERD, K. W. 1985. The structure and genetic control of a new class of disulphide-linked proteins in wheat endosperm. Theor. Appl. Genet., 71, 79-92.
SOZINOV, A. A. AND POPERELYA, F. A. 1980. Genetic classification of prolamins and its use for plant breeding. Ann. Technol. Agric., 29, 229-245. 